\title{
Dimension of an Islamic Model \\ Value on the Existence of Syariah Waltmart
}

Iskandar Muda

\author{
Faculty of Economics and Business, Accounting Department, Universitas \\ Sumatera Utara, Medan, Indonesia
}

Windari

Faculty of Economics and Business, Accounting Department, Institut Agama Islam Negeri, Padang Sidempuan, Indonesia

\begin{abstract}
Purpose - The purpose of this research is to know the Dimension of an Islamic Model Value on the
Abstract
Purpose - The purpose of this research is to know the Dimension of an Islamic Model Value on the existence of waltmart Syariah, Indonesia.

Design/Methodology/Approach - The data used are primary data sources. The method of analysis used in this research is SEM method using Smart PLS software.

Finding - The show results that customer satisfaction are formed from traditional and Islamic value dimensions.

Research Limitations/Implication - The implications of this research are the need to socialize the concept of Islamic value dimensions to the general public so that the public understanding of Islamic value dimensions is wider and easier to understand.

Originality/Value - This study is worth a new finding because it analyzes the scope of understanding of the value of Islamic value dimensions in Sharia Waltmart prospective buyers.
\end{abstract}

Keywords Islamic value dimension, traditional value dimension, Sharia Waltmart

All papers within this proceedings volume have been peer reviewed by the scientific committee of the Malikussaleh International Conference on Multidisciplinary Studies (MICoMS 2017).

\section{Introduction}

Small and medium-sized enterprises (SMEs) play an essential role in economic growth through job creation, employment, investment, and innovation. Therefore, SMEs' access to capital should not be limited and constrained (Huda, 2017; Lajis, 2017). Walmart has bowed to political correctness and is now offering meat that has been prepared halal style to appease about 50 Muslims in its Oxford, Ohio location (Straub, 2014). While this only applies to this one Wal-Mart store you can be certain it would not be the only one. The growth of supermarkets in Indonesia today shows a very rapid increase. Supermarket from abroad was not long to start popping up and they began to enter the various major cities in

(C) Iskandar Muda, Windari. Published in the Emerald Reach Proceedings Series. Published by Emerald Publishing Limited. This article is published under the Creative Commons Attribution (CC BY 4.0) licence. Anyone may reproduce, distribute, translate and create derivative works of this article (for both commercial and non-commercial purposes), subject to full attribution to the original publication and authors. The full terms of this licence may be seen at http://creativecommons.org/ licences/by/4.0/legalcode

Dimension of an Islamic Model Value

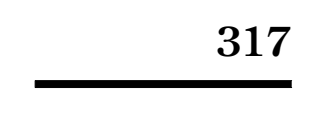


Proceedings of MICoMS 2017

\section{8}

Indonesia (Ferine et al., 2017; Huda, 2017; Lajis, 2017). These developments cannot be separated from the size of Indonesia's market potential of $80 \%$ Muslim. So the idea of the necessity of establishing Sharia self-service stores is a necessity so that this market potential is not merely used by "foreigners and idlers." Normatively, Muslims need guaranteed availability of halal products. On the other hand, the need for a sharia supermarket model needs to be answered so that the implementation of sharia values in the distribution of products and services to the Muslims can be more developed (Huda, 2017). The orientation for the territory of Indonesia to be a religious territory seems to require a minimally professionally managed shariah model and widespread benefits to the ummah. There are at least three fundamental reasons that become the basis of thinking for us to feel the need to make a minimarket sharia, namely Normatively, Muslims are required to provide a shopping center that ensures the availability of halal products, thayyib and blessings. The service model must be Islamic not merely symbolic of fashion and ornament but also the principles of hospitality, justice, and brotherhood (Farooq, 2009; Omar et al., 2010; Askari et al., 2012; Mirakhor, 2012; Ali et al., 2013; Zamir and Mirakhor, 2013; Farooq, 2014). Sociologically, the obligation is stronger considering the majority of the population/ citizens of Islam. This sharia minimarket will be a family shopping center. In addition, it is also a media promotion and distribution of goods for other Muslim producers. Economically, this business has a good prospect considering the big market. This sharia minimarket is expected to inspire a new spirit of Muslims in strengthening its economic position widely.

\section{Methods}

The type of this research is Comparative Research. Comparative research involves a wide variety of statistical techniques (Badaruddin et al., 2017; Muda, 2017; Muda, 2018; Syahyunan et al., 2017). The basic design of comparative research involves selecting two different groups on several independent variables and comparing them with several dependent variables. Both groups may be different, one group has characteristics that have no other. Or both groups differ in levels; one group has more than one characteristic than the other groups may have different types of experience (Achmad and Muda, 2017; Badaruddin et al., 2017; Dalimunthe and Muda, 2017; Lubis et al., 2017; Sihombing et al., 2017). This study uses Traditional dimension consisting of Emotional, Quality value, Social value, and value of Money. While Islamic Value Dimension using indicators of behavior, Marketing Strategy, Religious and Riba Concept (Farooq, 2014). The customer satisfaction element consists of Assurance, Emphaty, Reliable, Responsiveness, and Tangible with 127 respondents.

\section{Result and discussion}

\subsection{Result}

3.1.1. Evaluation of structural model. Inner model evaluation through the bootsraping menu also generates $T_{\text {statistics }}$ values that will be used to test the hypothesis. The criteria are $T_{\text {statistic }}>1.66$ (Marhayanie et al., 2017; Muda et al., 2017; Sirojuzilam and Muda, 2017). If the value of $t_{\text {count }}<t_{\text {table }}$, then $H_{0}$ accepted and when the value of $t_{\text {count }}>t_{\text {table }}$ then $H_{0}$ is rejected which means that the variable in question there is influence which is significant (Nurlina and Muda, 2017). This means that the independent variables tested have an effect significantly to the dependent variable. The result of $t$-statistics value in the table path coefficients is presented in Figure 1.

The effect test can be seen in Table 1 .

Table 1 produces a coefficient of 0.005 , smaller than $1 \alpha=5 \%$ then the decision of hypothesis testing rejects $H_{0}$ and accepts the hypothesis $H_{\mathrm{a}}$ (Muda, 2017). The results show 


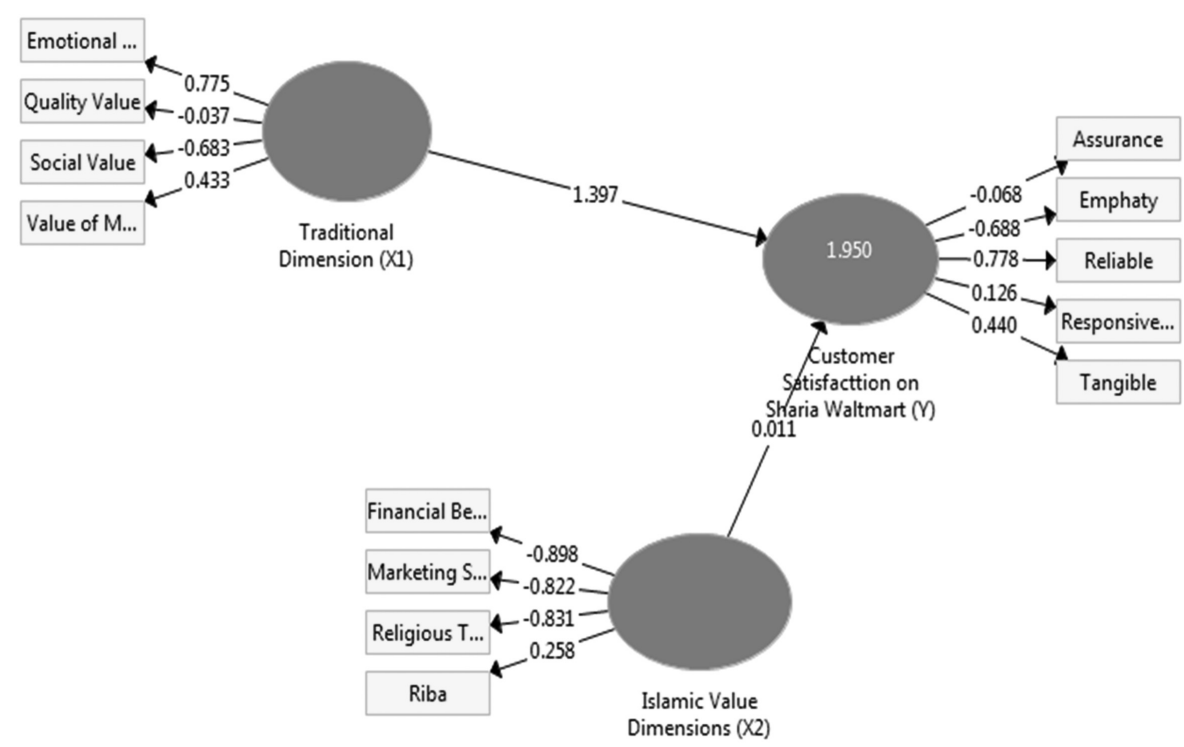

Dimension of an Islamic Model Value

Figure 1.

Overall Model with Co-efficient

\begin{tabular}{|c|c|c|c|c|c|c|}
\hline & $\begin{array}{l}\text { Original } \\
\text { Sample }\end{array}$ & $\begin{array}{l}\text { Sample } \\
\text { Mean }\end{array}$ & $\begin{array}{l}\text { Standard } \\
\text { Deviation }\end{array}$ & $\begin{array}{c}T \\
\text { Statistics }\end{array}$ & $\begin{array}{c}P \\
\text { Values }\end{array}$ & \\
\hline $\begin{array}{l}\text { Islamic Value Dimensions }(X 2) \text {-> Customer } \\
\text { Satisfaction on Sharia Waltmart }(Y)\end{array}$ & -0.014 & 0.005 & 0.022 & 0.602 & 0.547 & Table 1. \\
\hline $\begin{array}{l}\text { Traditional Dimension }(X 1)->\text { Customer } \\
\text { Satisfaction on Sharia Waltmart }(Y)\end{array}$ & 0.995 & 0.972 & 0.197 & 5.048 & 0.000 & $\begin{array}{l}\text { The Result of } \\
\text { Bootsraping }\end{array}$ \\
\hline
\end{tabular}

\begin{tabular}{lccc}
\hline & $R$ Square & $R$ Square Adjusted & $\begin{array}{r}\text { Table 2. } \\
R \text {-Square Value }\end{array}$ \\
\hline Customer Satisfaction on Sharia Waltmart $(Y)$ & 0.150 & 0.135 & \\
\hline
\end{tabular}

that Traditional Dimensions are significant variables on Customer Satisfaction on Sharia Waltmart $(Y)$. In addition to hypothesis testing through the bootsrapping menu that produces $T$-statistics, inner model evaluation is also done by reviewing the $R$-Square value (Asmeri et al., 2017; Honggowati et al., 2017; Jones et al., 2017; Khoiruman and Haryanto, 2017; Rahmawati et al., 2017; Suprianto et al., 2017). The $R$ square value generated from the inner model evaluation is presented in Table 2 and Figure 2.

The variation of $R$-Square value of $63.3 \%$. The Traditional Dimensions are significant variables on Customer Satisfaction on Sharia Waltmart (Y). Mart (modern market) which already has big names in Medan, Indonesia, is mostly owned by foreign parties and applied based on the conventional principle has gripped the people's market. As a result, slowly the 


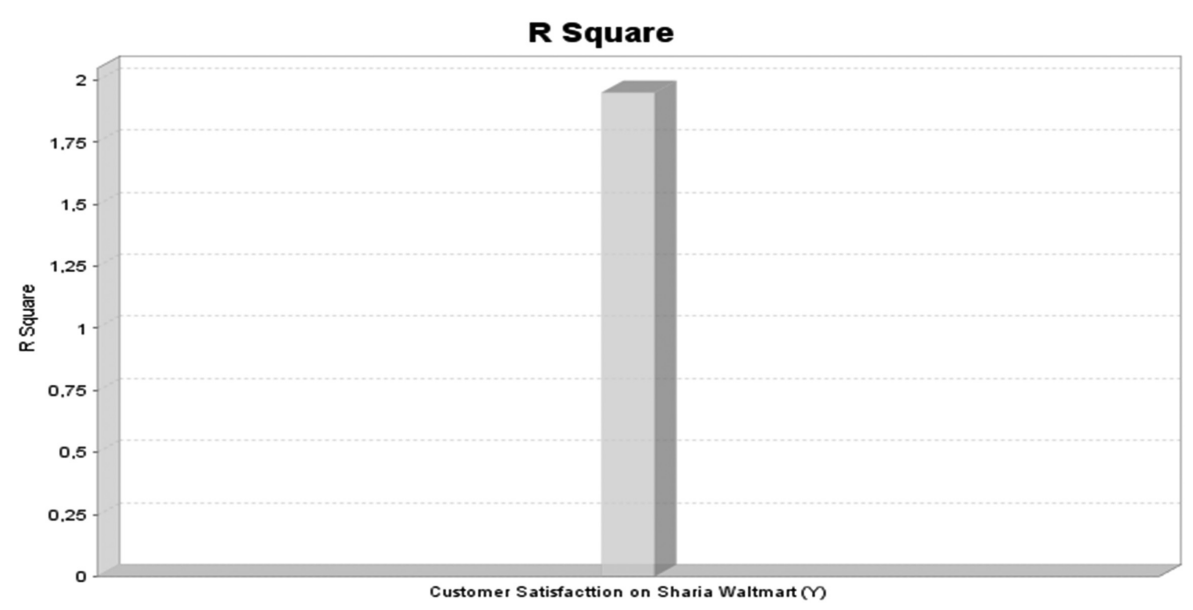

Figure 2.

trade by the small people will be eliminated, coupled with the problem of halalness of a product offered on the Mart. In Islamic teachings, there are halal and haram rules that have ordered us to eat only halal and good food, two unity cannot be separated, which can be interpreted halal in terms of sharia and good in terms of health, nutrition, aesthetics, and others. Although various foods and beverages and other products sold freely in the market, not least in supermarkets or minimarkets and the like. So it is not surprising that there are still many products offered there is a product that is still no halal label from Halal Authorized Institution. There should be protection for consumers with the inclusion of halal labels and the expiration date of a product. Seeing from what happened, came the idea for the development of Mart with the concept of sharia. In it, there is a profit-sharing system that is certainly not detrimental to both producers and traders and the main focus of sales not only on profitability but also contains social elements for the less fortunate. In addition, the level of halal either from capital, products offered, until the service, or existing facilities are also guaranteed. The existence of Mart Shariah as a form of concern for the ummah, it can be concluded that Mart Shariah is a market that there are principles of sharia in running it.

The "goodness" of the sold, the capital, and the services provided are the main things that distinguish the conventional modern market, which certainly contains the element of blessing in it (Muda et al., 2014). The existence of the giving of zakat, sodaqah to the surrounding community is also another characteristic of Mart Shariah. This shows that the Syariah Mart is not only focused on the effort to seek profit but also attention to the element of social concern for each other. The selection of qualified human resources who understand the religion in running the Mart Syariah, increasingly perfect this Mart Shariah. The existence of qualified human resources will support the application of religious values such as the value of honesty to be easily applied in the Mart sharia. Satisfactory service to the consumer is also easy to run and improved with the existence of qualified human resources.

\section{Limitation and implications}

The implications of this research are the need to socialize the concept of Islamic value dimensions to the general public so that the public understanding of Islamic value dimensions is wider and easier to understand. 


\section{Conclusions}

The show results that customer satisfaction is formed from traditional and Islamic value dimensions. The traditional dimensions are significant variables on customer satisfaction on Sharia Waltmart.

\section{References}

Achmad, N. and Muda, I. (2017). "Economic Activities of Karo Older Adults in Lingga Village, Tanah Karo Regency, North Sumatera, Indonesia”. International Journal of Economic Research, Vol. 14, No. 16, pp. 365-379.

Ali, S.S., Shirazi, N.S. and Nabi, M.S. (2013). "The Role of Islamic Finance in the Development of the IDB Member Countries: A Case Study of the Kyrgyz Republic and Tajikistan”. Islamic Economic Studies, Vol. 21, No.2, pp. 121-129. DOI: 10.12816/0001562.

Askari, H., Iqbal, Z., Krichene, N. and Mirakhor, A. (2012). Risk Sharing in Finance: The Islamic Finance Alternative. John Wiley \& Sons, Singapore.

Asmeri, R., Alvionita, T. and Gunardi, A. (2017). "CSR Disclosures in the Mining Industry: Empirical Evidence from Listed Mining Firms in Indonesia". Indonesian Journal of Sustainability Accounting and Management, Vol. 1, No. 1, pp. 16-22. DOI: 10.28992/ijsam.v1i1.23.

Badaruddin, Revida, E., Ermansyah and Muda, I. (2017). "Village Governance with Implementation of Law Number 6 of 2014 on the Village and Village Administration”. International Journal of Economic Research, Vol. 14, No. 16, pp. 350-363.

Dalimunthe, D.M.J. and Muda, I. (2017). "The Empirical Effect of Education and Training to the Performance of Employees". International Journal of Applied Business and Economic Research, Vol. 15, No. 24, pp. 5423-5437.

Farooq, M. (2009). "Islam and the Ribā-Interest Equation: Reexamination of the Traditional Arguments". Global Journal of Finance and Economics, Vol. 6, No. 2, pp. 99-111.

Farooq, M.O. (2014). "Islamic Wealth Management and the Pursuit of Positive-Sum Solutions". Islamic Economic Studies, Vol. 22, No. 2, pp. 99-124.

Ferine, K.F., Ermiaty, C. and Muda, I. (2017). "The Impact of Entrepreneurship and Competence on Small Medium Enterprises Tangan Di Atas (TDA) Medan Entrepreneurs' Work Performance". International Journal of Economic Research, Vol. 14, No. 16, pp. 380-393.

Honggowati, S., Rahmawati, R., Aryani, Y.A. and Probohudono, A.N. (2017). "Corporate Governance and Strategic Management Accounting Disclosure". Indonesian Journal of Sustainability Accounting and Management, Vol. 1, No. 1, pp. 23-30. DOI: 10.28992/ijsam.v1i1.24.

Huda, Q. (2017). “Summary Minimarket 212 Syariah”. Available: http://qaryatulhuda.blogspot.co.id/ 2016/12/summary-minimarket-212-syariah.html [accessed on 12 November 2017].

Jones, P., Wynn, M., Hillier, D. and Comfort, D. (2017). "The Sustainable Development Goals and Information and Communication Technologies". Indonesian Journal of Sustainability Accounting and Management, Vol. 1, No. 1, pp. 1-15. DOI: 10.28992/ijsam.v1i1.22.

Khoiruman, M. and Haryanto, A.T. (2017). "Green Purchasing Behavior Analysis of Government Policy about Paid Plastic Bags". Indonesian Journal of Sustainability Accounting and Management, Vol. 1, No. 1, pp. 31-39. DOI: 10.28992/ijsam.v1i1.25.

Lajis, S.M. (2017). "Risk-Sharing Securities: Accelerating Finance for SMEs". Islamic Economic Studies, Vol. 25, No. 2, pp. 35-55. DOI: 10.12816/0038221.

Lubis, A., Rustam and Muda, I. (2017). "Factors Affecting the Cost of Agency of Village Owned Enterprise (BUMDES) in Indonesia”. International Journal of Economic Research, Vol. 14, No. 16, pp. 334-348.

Marhayanie, Ismail, M. and Muda, I. (2017). "Impact of the Online Car Rental Service Order System on Sales Turnover with Financial Literacy Customer as Intervening Variables". International Journal of Economic Perspectives, Vol. 14, No. 16, pp. 317-332. 
Proceedings of Mirakhor, A. (2012). "Sharī'ah Compliant Macroeconomic Policy”. In 2nd ISRA Colloquium.

MICoMS 2017 Muda, I. (2017). "The Effect of Allocation of Dividend of the Regional Government-Owned Enterprises and the Empowerment Efforts on the Revenue of Regional Government: The Case of Indonesia". European Research Studies Journal. Vol. XX, No. 3A, pp. 223-246.

Muda, I, Rahmanta, S.A. and Marhayanie. (2017). "The Role of Working Capital, Productivity, Applied Technology and Selling Market Prices on Fisherman's Revenues". International Journal of Economic Research. Vol. 14, No. 16, pp. 291-302.

Muda, I., Rafiki, A. and Harahap, M.R. (2014). "Factors Influencing Employees' Performance: A Study on the Islamic Banks in Indonesia”. International Journal of Business and Social Science, Vol. 5 , No. 2, pp. 73-80.

Muda, I, Weldi, M., Siregar, H.S. and Indra, N. (2018). "The Analysis of Effects of Good Corporate Governance on Earnings Management in Indonesia with Panel Data Approach". Iranian Economic Review, Vol. 22, No. 2, pp. 657-669.

Nurlina and Muda, I. (2017). "The Analysis of the Effects of Capital Expenditure and Human Development Index on Economic Growth and Poverty in East Aceh Regency”. International Journal of Economic Research, Vol. 14, No. 16, pp. 395-409.

Omar, M.A., Md Noor, A. and Mydin Meera A.K. (2010). "Islamic Pricing Benchmark". ISRA OMAR Research Paper, No. 16, pp. 29-37.

Rahmawati, R., Rispantyo, R. and Djamaluddin, S. (2017). "Mentoring Function and Quality of Supervisor Auditor Relationship: Organizational Justice as a Mediation”. Indonesian Journal of Sustainability Accounting and Management, Vol. 1, No. 1, pp. 40-48. DOI: 10.28992/ijsam. v1i1.26.

Sihombing, M., Muda, I., Jumilawati, E. and Dharsuky, A. (2017). "Factors Affecting the Success of Local Innovation Systems with Government Programs as Moderators". International Journal of Economic Research, Vol. 14, No. 16, pp. 272-289.

Sirojuzilam, H.S. and Muda, I. (2017). "Effect of Private Collaborative as a Moderation of Success of Agropolitan Program”. International Journal of Economic Research, Vol. 14, No. 16, pp. 304-315.

Straub, S. (2014). "Walmart Bows to Political Correctness, Makes Big Change to Accommodate Muslims”. Available: http://thefederalistpapers.org/us/walmart-bows-to-political-correctnessmakes-big-change-to-accomodate-muslims [accessed 12 November 2017].

Suprianto, E., Suwarno, S., Murtini, H., Rahmawati, R. and Sawitri, D. (2017). "Audit Committee Accounting Expert and Earnings Management with "Status" Audit Committee as Moderating Variable". Indonesian Journal of Sustainability Accounting and Management, Vol. 1, No. 2, pp. 49-58. DOI: 10.28992/ijsam.v1i2.16.

Syahyunan, Muda, I, Siregar, H.S, Sadalia, I. and Chandra, G. (2017). "The Effect of Learner Index and Income Diversification on the General Bank Stability in Indonesia”. Banks and Bank Systems, Vol. 12, No. 4, pp. 56-64. DOI: http://10.21511/bbs.12(4).2017.05.

Zamir, I. and Mirakhor, A. (2013). "Economic Development and Islamic Finance". Islamic Economic Studies, Vol. 2, No. 1, pp. 245-247. DOI: 10.12816/0004138.

\section{Corresponding author}

Iskandar Muda can be contacted at iskandar1@usu.ac.id 